\title{
Adverse reactions associated with a Fuenzalida-Palacios rabies vaccine: a quasi-experimental study
}

\author{
Reações adversas associadas com uma vacina anti-rábica tipo \\ Fuenzalida-Palacios: um estudo quase-experimental
}

\author{
Rosuita Fratari Bonito $\quad{ }^{1}$, Neide Mattar de Oliveira ${ }^{1}$ and Sérgio de Andrade Nishioka ${ }^{1}$
}

\begin{abstract}
The Fuenzalida-Palacios rabies vaccine has been used in South America for rabies post-exposure prophylaxis. To determine the frequency of adverse reactions associated with this vaccine compared to a control group a quasi-experimental study was carried out in Uberlândia, Brazil, from May 1997 to April 1998. Victims of bites or other injuries by dogs or other mammals and who received or not post-exposure prophylaxis with Fuenzalida-Palacios rabies vaccine were compared as to the occurrence of a list of signs and symptoms. Out of 2,440 victims of bites and other injuries from dogs and other mammals 2,114 participated in the study; 1,004 of them provided follow-up information within 10 to 15 days. Headache and pain at the injection sites were the most commonly found symptoms (125/1,000). No neuroparalytic event was detected. Patients who were given Fuenzalida-Palacios rabies vaccine and those who were not had similar incidences of symptoms (risk ratios close to 1). Regarding the occurrence of adverse reactions, Fuenzalida-Palacios rabies vaccine is a valid alternative for rabies post-exposure prophylaxis.
\end{abstract}

Key-words: Adverse reaction. Fuenzalida-Palacios vaccine. Post-exposure prophylaxis. Quasi-experimental study. Rabies vaccine.

\section{RESUMO}

A vacina anti-rábica tipo Fuenzalida-Palacios é utilizada na América do Sul para a profilaxia anti-rábica pós-exposição. Um estudo quase-experimental foi realizado em Uberlândia, Brasil, de maio de 1997 a abril de 1998, para determinar a freqüência de reações adversas associadas a esta vacina. Vítimas de mordeduras e outras lesões causadas por cães ou outros mamiferos que receberam ou não vacina anti-rábica tipo Fuenzalida-Palacios como profilaxia pós-exposição foram comparados quanto à ocorrência de uma série de sinais e sintomas. As informações sobre esses eventos foram obtidas por entrevistas pessoais ou por telefone. De 2.440 vítimas de mordeduras e outros traumatismos por cães ou outros mamiferos 2.114 participaram do estudo; 1004 forneceram informações sobre ocorrência de sintomas dentro de 10 a 15 dias. Cefaléia e dor nos locais das injeções foram os sintomas mais freqüentes (125/1.000). Nenhum evento neuroparalítico foi detectado. Pacientes que receberam ou não a vacina anti-rábica tiveram incidências semelhantes de reações adversas (razões de risco próximas a 1). No que diz respeito à ocorrência de reações adversas, a vacina anti-rábica tipo Fuenzalida-Palacios é uma alternativa válida para a profilaxia anti-rábica pós-exposição.

Palauras-chaves : Estudo quase-experimental. Profilaxia pós-exposição. Reação adversa. Vacina anti-rábica. Vacina Fuenzalida-Palacios.

Rabies remains an important health problem in the tropics, where it is mostly associated with bites from dogs and, to a lesser extent, other mammals, including bats. Rabies is almost invariably fatal, but can be prevented by post-exposure prophylaxis with rabies vaccine and antirabies serum. Pre-exposure rabies vaccination has been indicated only for professionals who are considered to be at high risk of acquiring rabies, such as veterinarians, mammal biologists, and dog catchers.
Several types of rabies vaccine have been used since Pasteur developed the first one over a century ago, using viruses that were maintained through multiple passages in rabbit spinal cord and inactivated by drying ${ }^{9}{ }^{12}$. Diploid cell vaccines are presently considered the best rabies vaccines taking into account their high efficacy and low incidence of adverse reactions, but they are expensive and seldom available in developing countries. In South America, Fuenzalida-Palacios rabies vaccine ${ }^{3}$, which uses inactivated

\footnotetext{
1. Departamento de Clínica Médica da Faculdade de Medicina da Universidade Federal de Uberlândia, Uberlândia, MG, Brazil.

This study was approved by the Committee of Ethics in Research of the Universidade Federal de Uberlândia.

Address to: Dr. Sérgio de Andrade Nishioka. Al. Sosthenes Guimarães 667, 38411-160 Uberlândia, MG, Brazil

Tel: 5534 3255-2328, Fax: 5534 3218-2349

e-mail: sergio.nishioka@anvisa.gov.br

Recebido para publicação em 5/8/2002

Aceito em 22/9/2003
} 
viruses prepared from suckling mouse brains, has been used for decades as an acceptable alternative to diploid cell vaccine given its comparable efficacy (although requiring a higher number of doses) and much lower cost. The drawback of nerve tissue-containing vaccines is the risk of neuroparalytic adverse reactions that is associated with them. The incidence of neurological complications was 1/200 (7 out of 1,392) in adults who received a Semple-type phenol inactivated lamb nerve tissue vaccine in Tunisia; these manifestations occurred a median of 11 days after the first vaccine injection ${ }^{2}$. These events are rarer for the Fuenzalida-Palacios vaccine, which by using suckling mouse brain as substrate has a decreased myelin content. The incidence of neuroparalytic reactions associated with this vaccine in a Mexican series was 27.6 per million doses 9 . More recent figures from the Brazilian literature for the state of São Paulo range from rates of 1:3,263 (1997) $)^{11}$ to $1: 34,533(1980-1990)^{5}$. A retrospective study from Osasco, in São Paulo state, detected one neurological complication in 8,758 individuals submitted to post-exposure prophylaxis 5 . Notwithstanding their rarity, a few cases of neurological adverse reactions are expected to occur given the large number of individuals who require post-exposure rabies prophylaxis, over 280,000 per year in Latin America ${ }^{1}$.

Surprisingly very little has been published on Fuenzalida-Palacios rabies vaccine-associated adverse reactions other than its neurotoxicity. Data from Latin America reveal that erythema, urticaria/pruritus, and lymphadenopathy occur respectively in $2 / 3,1 / 3$ and $1 / 4$ of the individuals who are vaccinated ${ }^{9}$. A study from Nigeria, on the other hand, reported an incidence of $11.1 \%$ of local reactions and of $2.5 \%$ generalised reactions among individuals who received a suckling mouse brain vaccine ${ }^{6}$. The scarcity of data was the motivation for the undertaking of this study, the aim of which was to assess the incidence of adverse reactions associated with a Fuenzalida-Palacios rabies vaccine.

\section{PATIENTS AND METHODS}

Aclinical trial with patients receiving or not rabies vaccine at random would be unethical. We took advantage of the fact that the Brazilian Ministry of Health's guidelines recommend post-exposure (FuenzalidaPalacios) rabies vaccine only to certain types of wounds and in certain circumstances ${ }^{4}$ to design instead a quasi-experimental study ${ }^{81013}$. In this design, a cohort of individuals injured (usually bitten) by dogs and other mammals was followed up over time and the occurrence of a number of symptoms was compared between those who were given post-exposure rabies vaccine and those who were not. The criteria for vaccine administration were those of the Brazilian Ministry of Health ${ }^{4}$. The rabies vaccine used throughout the study was manufactured by the Instituto de Tecnologia do Paraná (TECPAR), Curitiba, Brazil.

Face-to-face or telephone interviews were carried out by trained interviewers 10 to 15 days, and then 30 to 40 days after the injury (animal bite). In these interviews questions were asked to the participants or caregivers about the occurrence of symptoms that included those already expected to be associated with FuenzalidaPalacios rabies vaccine, and also others that were unlikely to be associated with it. The latter were included in the questionnaire to assess the possible occurrence of information bias 8 . The finding of several clinical manifestations to be more common among individuals who were vaccinated, including some unlikely to be associated with the vaccine, would suggest that those who received the vaccine were over-reporting symptoms.

The sample size calculation took into account previous data that indicated that about 2,400 (200 per month) individuals could be expected to be injured by mammals in Uberlândia in a period of 12 months, and that about 40 percent of them would require post-exposure rabies prophylaxis. This sample size of 2,400 would have a power of 80 percent to detect risk ratios of 2.7 and 6.5 for incidences of clinical manifestations of respectively 10 per 1,000 and 2 per 1,000 among the individuals who did not receive the vaccine. In the statistical analysis, comparisons between continuous variables were made with the $t$ test. Comparisons of the incidences of symptoms between the two groups were made by the calculation of risk ratios (RR) with $95 \%$ confidence intervals, and by significance tests (chi square or Fisher's exact test, wherever appropriate). The EpiInfo package (Centers for Disease Control, Atlanta, $\mathrm{GA}$ ), version $6.04 \mathrm{~b}$, was used for the statistical analysis.

\section{RESUL TS}

A total of 2,440 individuals injured by dogs and other mammals were attended at the Unidade Básica de Saúde Fausto Savastano, Uberlândia's reference centre for rabies prophylaxis, from 1 May 1997 to 30 April 1998. All patients had their baseline data registered, except 326 who were excluded from the study because their charts were incomplete. Out of the remaining 2,114 individuals, 1,684 $(79.7 \%)$ received rabies vaccine whereas 430 (20.3\%) did not. Age and sex distribution did not differ between the two groups. Only 55 $(3.3 \%)$ of the patients who were vaccinated also received antirabies serum. The number of individuals who answered the questionnaire between the $10^{\text {th }}$ and $15^{\text {th }}$ days after the injury, and between the $30^{\text {th }}$ and $40^{\text {th }}$ days were, respectively, 1,004 (47.5\%) and $542(25.6 \%)$.

The incidences of symptoms among the individuals who received the vaccine are shown in Table 1. Headache and pain at the injection sites were reported most frequently, with an incidence of around 125 per 1,000 individuals within 10 to 15 days after the start of the vaccination schedule.

Table 1 - Incidence per 1,000 individuals of selected (the most common) early (those occurring during the first 10 to 15 days) and late (those occurring later up to 30 to 40 days) adverse events (symptoms) among victims of animal injuries who were given Fuenzalida-Palacios rabies vaccine, Uberlândia, May 1997 to April 1998.

\begin{tabular}{lcc}
\hline & Time after Fuenzalida rabies vaccine (days) \\
\cline { 2 - 3 } Adverse event & $10-15$ & $30-40$ \\
\hline Local (in or around the injection sites) & & \\
pain & 236 & 86 \\
pruritus & 275 & 102 \\
edema & 279 & 70 \\
erythema & 190 & 50 \\
Systemic & & \\
headache & 124 & 79 \\
fever & 76 & 32 \\
insomnia & 64 & 48 \\
nausea & 43 & 16 \\
myalgia & 42 & 20 \\
urticariform rash & 32 & 39 \\
lymphadenopathy & 26 & 7 \\
arthralgia & 21 & 11 \\
\hline
\end{tabular}


Table 2 - Frequency of selected symptoms reported during the first 10 to 15 days among victims of animal injuries who were given or not Fuenzalida-Palacios rabies vaccine, Uberlândia, May 1997 to April 1998, and risk ratios with 95\% confidence intervals.

\begin{tabular}{|c|c|c|c|c|c|c|c|}
\hline \multirow[b]{2}{*}{ Symptom } & \multirow{2}{*}{$\begin{array}{l}\text { No. of } \\
\text { patients }\end{array}$} & \multicolumn{2}{|c|}{ Vaccinated } & \multicolumn{2}{|c|}{ Non vaccinated } & \multirow{2}{*}{$\begin{array}{l}\text { Risk ratio } \\
(95 \% \mathrm{CI})\end{array}$} & \multirow[b]{2}{*}{$p^{*}$} \\
\hline & & Present & Absent & Present & Absent & & \\
\hline headache & 1001 & 101 & 711 & 21 & 168 & $1.12(0.72-1.74)$ & 0.62 \\
\hline fever & 1002 & 62 & 751 & 9 & 180 & $1.60(0.81-3.16)$ & 0.17 \\
\hline insomnia & 1004 & 52 & 763 & 10 & 179 & $1.21(0.62-2.33)$ & 0.58 \\
\hline nausea & 1004 & 35 & 780 & 7 & 182 & $1.16(0.52-2.57)$ & 0.71 \\
\hline myalgia & 1002 & 34 & 779 & 7 & 182 & $1.13(0.51-2.51)$ & 0.76 \\
\hline rash (urticariform) & 1004 & 26 & 789 & 3 & 186 & $2.01(0.61-6.57)$ & 0.24 \\
\hline rash (nonpruriginous) & 1004 & 8 & 807 & 1 & 188 & $1.86(0.23-14.74)$ & $1.00^{* *}$ \\
\hline lymphadenopathy & 1003 & 21 & 793 & 2 & 187 & $2.44(0.58-10.31)$ & $0.28^{* * *}$ \\
\hline arthralgia & 1002 & 17 & 796 & 5 & 184 & $0.79(0.30-2.12)$ & $0.59^{* * *}$ \\
\hline toothache & 1004 & 4 & 811 & 5 & 184 & $0.19(0.05-0.68)$ & $0.01^{\text {*** }}$ \\
\hline
\end{tabular}

* Chi-square unless otherwise stated; ** Fisher's exact test

No case of neuroparalytic accident was detected through the interviews. Only one patient had a skin rash classified as severe but that responded well to oral chlorpheniramine. The risk ratios of certain signs and symptoms among individuals who received or not Fuenzalida rabies vaccine were generally close to 1, with $95 \%$ confidence intervals including the unit (Table 2). Only the incidence of one symptom (toothache during the first 10 to15 days) was significantly different between the two groups, and was higher among the individuals who were not vaccinated.

\section{DISCUSSION}

Although the Fuenzalida-Palacios rabies vaccine has been used in South American countries since the 1960s, very little is available in the literature about the incidence of associated adverse reactions. Even the reports of severe adverse reactions that can be either life-threatening or lead to permanent disability, such as neuroparalytic accidents, are few, and a detailed analysis of a causal relationship is not available.

The findings of this study suggest that Fuenzalida-Palacios rabies vaccine is safe, based on the absence of detection of severe adverse reactions. This study had a sample size that was insufficient for the detection of relative risks of low magnitude. Nevertheless it is unlikely that lack of statistical power explained the failure to detect more common adverse reactions, given that the risk ratio estimates were close to 1 and the confidence intervals relatively narrow. Bias due to nonparticipation could be a concern giving the low proportion of participants in the study who responded to the follow-up interviews. However, if participation varies according to likelihood of exposure but not disease then the risk ratio is not biased ${ }^{7}$. Information bias is unlikely to have occurred as no trend suggestive of over- or underreporting of symptoms in any of the two groups of patients was detected. At least for neuroparalytic accidents it is very unlikely that underreporting has occurred, giving that cases which could be missed in the study should have been detected by the surveillance system existent in the Uberlândia region because of the program for poliomyelitis elimination, and none was notified. The finding that toothache was more common among individuals who were not vaccinated was most probably due to chance, given the large number of comparisons made. Although randomisation was not undertaken in this study, the allocation of patients to receive or not rabies vaccine was quasi-experimental, and therefore confounding factors should not be expected to threaten the validity of the findings.
Diploid cell rabies vaccines are considered the best rabies vaccines nowadays ${ }^{12}$, but their cost has limited its availability in many tropical countries. Until these vaccines become more affordable Fuenzalida-Palacios rabies vaccine remains a good alternative for post-exposure rabies prophylaxis in South America and perhaps elsewhere, where rabies remains an important public health problem ${ }^{6}$. Pharmacovigilance studies are still necessary to better estimate the occurrence of adverse reactions, particularly of neuroparalytic accidents, in different settings and populations.

\section{REFERENCES}

1. Anonymous. La situación de la rabia en America Latina de 1990 a 1994. Boletín de la Oficina Sanitaria Panamericana 119:451-456, 1995.

2. Bahri F, Letaief A, Ernez M, Elouni J, Chekir T, Bem Ammou S, Jemmi L. Les complications neurologiques observées chez l'adulte, secondaires au vaccin antirabique preparé sur cerveaux d' animaux. Presse Médicale 25:491-493, 1996.

3. Fuenzalida E, Palacios R, Borgono JM. Anti-rabies antibody response in man to vaccine made from infected suckling-mouse brains. Bulletin of the World Health Organization 30:431-436, 1964.

4. Fundação Nacional de Saúde. Norma técnica de tratamento profilático anti-rábico humano. Centro Nacional de Epidemiologia, Ministério da Saúde, Brasília, 1994.

5. Garcia RCM, Vasconcellos SA, Sakamoto SM, Lopez AC. Análise de tratamento anti-rábico humano pós-exposição em região da Grande São Paulo, Brasil. Revista de Saúde Pública 33:295-301, 1999.

6. Harry T0, Adeiga A, Anviwo CE, Nasidi A. Anti-rabies treatment of dog-bite victims in Lagos, Nigeria: trial of suckling mouse brain and fetal bovine kidney cell rabies vaccines. Vaccine 2:257-260, 1984.

7. Kelsey JL, Whittemore AS, Evans A, Thompson WD. Methods in Observational Epidemiology. $2^{\text {nd }}$ edition. Oxford University Press, New York, p. 106, 1996.

8. Kleinbaum DG, Kupper LL, Morgenstern H. Epidemiologic Research: principles and quantitative methods. Van Nostrand Reinhold, New York, p. 44-45, 1982.

9. Kumate J. Inmunidad, inmunización, vacunas. Ediciones Medicas del Hospital Infantil de Mexico, Mexico City, p. 191-210, 1977.

10. Nishioka SA. What exactly is a quasi-experimental study? American Journal of Preventive Medicine 21:152, 2001

11. Nogueira YL. Adverse effect versus quality control of the Fuenzalida-Palacios antirabies vaccine. Revista do Instituto de Medicina Tropical de São Paulo 40:295-299, 1998.

12. Plotkin SA, Rupprecht CE, Koprowski H. Rabies vaccine. In: Plotkin SA, Orenstein WA (eds) Vaccines. $3^{\text {rd }}$ edition. WB Saunders, Philadelphia, p. 743-766, 1999.

13. Rothman KJ, Greenland S. Types of epidemiologic studies. In: Rothman KJ, Greenland S (eds) $2^{\text {nd }}$ edition, Lippincott-Raven, Philadelphia, p. 67-78, 1998. 